\title{
The potential of speech act theory for New Testament exegesis: Some basic concepts
}

\author{
J E Botha \\ University of South Africa
}

\begin{abstract}
Exegetes and biblical scholars are increasingly utilising the precepts of modern literary and linguistic theories in dealing with the text of the Bible. Speech act theory as well offers New Testament exegesis some additional ways and means of approaching the text of the New Testament. This first in a series of two articles making a plea for the continued utilisation and application of this theory to the text of the New Testament, offers a brief discussion of the basic principles of the theory.
\end{abstract}

\section{INTRODUCTION}

The introduction of modern literary theory and linguistics into the reading and interpretation of the Bible in recent years has provided New Testament scholarship with new opportunities and new challenges. Exegetes and biblical scholars are increasingly utilising the precepts of modern literary and linguistic theories in dealing with the text of the Bible. This has become inevitable as the limitations of the historical paradigm have increasingly become evident. It is limited in that it is able to answer only questions put by historico-critical methodologies (Vorster 1984:119). These methodologies, with which biblical scholars have been operating since the last century, do not address or attempt to address questions regarding meaning, communication, function of language and so on. Naturally, this does not mean that the historical-critical methods have reached the end of the road, and are no longer valid. However, the results yielded by the historico-critical methodologies must be viewed for what they are and, if necessary, other methodologies of other paradigms which can provide further perspectives on the Bible should also be implemented by New Testament scholars. Aspects such as meaning in texts, reference, semantics, text theory, the narrative nature of many New Testament documents, function, and 
so on, all fall beyond the scope of the historico-critical approach, and must be addressed by methods designed for these endeavours. The implementation of these methods in recent years provides a very necessary correction to the historical-critical method, in the sense that New Testament scholarship so retains its nature as a textcentred or text-oriented science, and opposes the limited perception that New Testament science is primarily or only a historical science.

The shift from a historical approach to that of more text-oriented methodologies is evident from developments in recent years. I shall only offer a few examples to illustrate this point. The insights of modern narratology have been introduced into the study of New Testament narratives. Because the study of the New Testament entails both literary and historical aspects, it is inevitable that New Testament scholars should turn to theories of literature when dealing with texts. There are many narrative texts in the New Testament and, consequently, the implementation of modern narratology is a logical consequence (e g Culpepper 1987; Vorster 1986; Edwards 1985; Fowler 1982). Similarly, the introduction of reception theories into New Testament studies also gave a new impetus to the analysis of texts and brought to the fore the concept of the reader, and his creative contribution to the communication of the text (see Petersen 1984; Fowler 1985; Staley 1986; Eslinger 1987; Botha 1989). The influence of deconstruction on the study of the New Testament is also a significant new development which is greatly influencing perceptions of texts and their epistemological status. When we are dealing with reception theory, deconstruction and related theories, we must understand that we are moving beyond the historical-critical and structural approaches to that of post-structural literary theory (see Derrida 1976; Ryan 1985; Harley 1987), where the act of reading that 'creates a radically new text...becomes an active process of attributing meaning' (Vorster 1989:59); it also entails much more than the mere decoding of signs in texts. Based on the new structuralist perception of what texts are comes the notion of intertextuality (Broich \& Pfister 1985) which focuses on the intertwinement and interdependence of texts. "All texts can be regarded as the rewriting of previous texts, and also as reactions to texts... The phenomenon "text" becomes a network of traces, no longer a unitary object which is knowable, or a completed work with a centre and an edge which is recoverable by the skilled reader' (Vorster 1989:60). All these developments are changing the face of New Testament understanding, and the interpretation of texts. Another very significant newcomer to New Testament studies is speech act theory. This text theory has been introduced sporadically into research programmes over the past two decades, but has not received its due credit. Aurelio (1977), Arens (1982), Du Plessis (1985), Jacobs (1985), Wendland (1985) and Botha (1989) introduced aspects of this theory to New Testament studies. Volume 41 of 
Semeia (1988) was devoted to this and entitled Speech act theory and biblical criticism. Despite the immense possibilities offered to New Testament exegetes by this theory, only a few articles on this subject have been published. There could be several reasons for this: Firstly, the field of speech act theory is extremely divergent and to some extent very technical with approaches ranging from the language-philosophical to the pragmatic (see White 1988:4; Hutchinson 1984:3-34). New Testament scholars are often not trained linguists or literary scholars, and the immense field of speech act theory research makes this line of research somewhat impervious and difficult to master from scratch. Secondly, speech act theory is often discussed in theoretical terms, and practical applications to enable the 'uninitiated' to grasp the practical application and possibilities of the theory are seldom proposed. Third$l y$, the lack of publications on this theory (in New Testament studies in particular) is a clear indication that, because of the novelty of the application of this theory to biblical texts, some time needs to be allowed before it will be generally accepted in New Testament studies.

In this article I shall give a short description of the basics of speech act theory in such a way that even those who have previously not utilised the theory will (hopefully!) be able to see its advantages and begin to use it to some extent. I shall offer a few observations on the relevance of speech act theory for aiding the understanding and interpretation of New Testament texts in the next article. Because of the relative ignorance of the possibilities speech act theory has to offer exegetes and, because in New Testament scholarship we do not yet have systematic discussion of speech act theory, I have deemed it both necessary and worthwhile to discuss the basics of speech act theory here. I will attempt neither to relate the historical development of speech act theory here, nor discuss the philosophical background and presuppositions, but will rather give an indication of what the theory entails - in order to make it clear and accessible to those who desire to use it. I shall explain an approach to speech act theory here which has been termed centrist by White (1988: 4), as opposed to the rightist approach, where the focus is on speech acts with their contexts internal to the literary work, and the leftist approach, where the focus is very broadly on 'the performative function of language...in the constitution of subjectivity' (White 1988:4). The centrist position is basically an extension of the original theories of Searle (1977) and Austin (1975) by, inter alii, Grice (1975), Ohman (1973), Pratt (1977), and McLaughlin (1984). Van Coller \& Van Jaarsveld (1984) and Van Jaarsveld $(1982,1987)$ represent South African approaches to speech act theory, which may be grouped with the centrist position. 


\section{SOME FUNDAMENTAIS OF SPEECH ACT THEORY}

\subsection{Sentences versus utterances}

Whereas sentences are the object of study of formal semantics, speech act theory deals with utterances. Sentences are usually studied as abstract semantic and syntactical structures, which are abstracted from their real or pragmatic contexts. Utterances/speech acts are not viewed divorced from the pragmatics of language usage - that is, utterances made in a specific context have a specific 'force', not necessarily related to the form of utterance. For instance, the utterance 'It is raining' has that meaning but, depending on the context, the 'force' of the utterance could be that the speaker is using it to inform or to warn. Utterances can consist of a single sentence, a group of sentences, and even of a single word. The fact that speech act theory deals with speech acts as utterances allows for a very flexible concept in describing language usage.

\subsection{Performatives}

The concept of performatives is also a crucial distinction in speech act theory. Austin (1975:60) states that 'the issuing of the utterance is the performing of an action - it is not normally thought of as just saying something'. From this it follows that to speak is to perform an act. This concept was introduced by Austin because not all utterances in language can be viewed in terms of only true and false, that is, as mere statements or constatives. Performatives are the real speech acts in language, and are judged by criteria other than those applied to constatives. Constatives are judged in terms of true or false, whereas terms such as felicitous/infelicitous, happy/unhappy, appropriate/inappropriate, effective/ineffective and successful/unsuccessful are used to depict performatives/speech acts (see also Cloete 1984:2).

\subsection{Locution, illocution and perlocution}

The performative act encompasses three possible acts: the locutionary act, the illocutionary act and the perlocutionary act. The locutionary act is the act of producing a coherent and grammatically acceptable utterance. Within this locutionary act three additional acts occur which Austin (1975:92-93) distinguishes as a phonetic act, a phatic act and a rhetic act. In speech act analyses of texts, the locutionary act per se is very seldom studied as such. The emphasis is on illocution and perlocution. The study of locutionary acts can be very fruitful as Cloete (1984: 9-10) indicates, but it would seem that, for the analysis of the New Testament, emphasis on the illocution and perlocution would be more fruitful. The illocutionary $a c t$ is the act of producing an utterance with a certain illocutionary force, such as 
greeting, warning, ordering, pleading, requesting and so on. A number of taxonomies have been proposed for classifying speech acts such as those by Searle (1976), Austin (1975), Bach \& Harnish (1979:40-44), and Leech (1983:205-226). However, it must be realised that a rigid categorisation of speech acts in any language is not possible, and a flexibility should be observed in this respect. The perlocutionary act is the act by which the speaker intends to achieve certain effects in the hearer. For instance, by calling another person dumb, the intention could be to insult and hurt that person. The illocutionary force and the perlocution do not necessarily coincide. The illocutionary force of an act could be that of insulting someone, with the perlocutionary aim of motivating or challenging him/her. Cloete (1984:9) states: 'Literary perlocution is as old as literature itself....A peculiarity is that the literary perlocution can go completely against the illocution of the text - there could be something like 'illocutionary' and 'perlocutionary' fallacy, to translate the old 'intentional fallacy' into a new idiom. Again a point of concurrence with reception aesthetics.' (My translation of Afrikaans original.)

\subsection{Appropriateness conditions or felicitous conditions}

One of the fundamentals of language is that of being able to communicate. The users of language need to share some knowledge about the context and rules of the language and the rules of their verbal dealings with each other. Thus one of the key concepts of speech act theory, according to Searle (1977:22), is that 'speaking a language is engaging in a rule governed form of behaviour. To put it more briskly, talking is performing acts according to rules'.

Thus, in order to understand a verbal exchange and its specific manifestation in a specific context, it is necessary to identify the rules/conditions that are applicable to that specific situation and these must be met whenever people engage in such a communicative situation.

As users of language, people constantly rely on the shared knowledge of appropriateness conditions; the assumption that these rules have been met plays an important role in the success of the communication. The language user must choose, from the multitude of possible forms in his/her speech act, the most appropriate one for the particular situation. Equally important is the knowledge of certain rules which govern specific types of speech situation, which are important to understand in making the communication successful. These rules differ according to the relationship that exists between the speakers in a specific context. The illocutionary act of demanding implies that the speaker is in a position over and against the addressee so that he/she has the right to do so, or that he/she is in a position of authority, whereas for the act of pleading, the appropriateness conditions require 
that the addressee is in the position of authority. It is this knowledge of the appropriateness conditions that are valid within a specific context that enables speakers and addressees to distinguish for instance between 'That was clever!' as a compliment or a sarcastic statement. Furthermore, appropriateness conditions are also important from a linguistic point of view because they are a crucial component of the grammar of a language even though they represent aspects of an utterance which are not part of the explicit verbal structure' (Pratt 1977:83).

These appropriateness conditions must be observed, and they determine to a great extent the framework and rules which regulate any type of communication. This includes all rules and principles, both linguistic and extralinguistic, which govern utterances and conversation. The following concepts, which are discussed here, may be considered to be part of this general concept of appropriateness conditions. Some of the conditions are socially and culturally determined, but the more general rules are universals of language communication.

\subsection{The Cooperative Principle and maxims}

In line with the general concept of appropriateness conditions, Grice identified the 'Cooperative Principle and maxims' in a series of lectures entitled Jogic and conversation, which were partially published in 1975 . For Grice (1975) the important thing in language usage is the success of an utterance. For maximum efficacy, the speaker must keep to the Cooperative Principle. This implies that our communication is governed by 'a rough general principle which participants will be expected (ceteris paribus) to observe, viz: "Make your conversational contribution such as is required, at the stage at which it occurs, by the accepted purpose or direction of the talkexchange in which you are engaged"' (Grice 1975:45). In addition, Grice proposes four maxims, or large, general, appropriateness conditions that are normally assumed to be in force when any conversation takes place:

* Maxim of quantity: The rule is that a contribution to an exchange should be as informative as required: not more and not less. 'Be economical.'

- Maxim of quality: A contribution should be true - it must not be intentionally false and nothing should be said if the necessary evidence is lacking. 'Be sincere.'

- Maxim of relation: 'Be relevant.'

- Maxim of manner: 'Be perspicuous.' 
In addition to these four maxims introduced by Grice (1975), together with the general cooperation principle, Bach \& Harnish (1979:64) introduced two more: the politeness maxim and the morality maxim, and describe these as:

- Politeness: The speaker (in speaking) behaves politely, that is, he/she is not offensive, abusive, rude, vulgar.

* Morality: The speaker (in speaking) behaves morally, that is, he/she:

i does not reveal information he ought not reveal;

ii does not ask for information he should not have;

iii does not direct someone to do/tell something that person should not do/tell;

iv does not commit himself/herself to do something for someone which that person does not want done.

Bach \& Harnish (1979:68) also propose a general principle of charity, which states: 'Other things being equal, construe the speaker's remarks so as to violate as few maxims as possible.' Finally, Leech (1983:7-17), in adding to and extending Grice's 1975 scheme, proposes two different sets of conversational principles/maxims which govern any goal-oriented speech situation: the level of interpersonal rhetoric and the level of textual rhetoric. (See Du Plessis 1985:16-22 for an elaborate discussion of Leech's theory.)

These rules, principles or maxims are the unwritten requirements without which communication would be virtually impossible.

\subsection{Implicature}

Because of the importance of the observation of certain rules in speech act theory, the (deliberate) breaking or non-observance of rules is equally important. Grice (1975:49) lists a number of cases in which the CP (Cooperation Principle) or maxims are deliberately not fulfilled. Three of these are not applicable to works of literature, but the fourth (i e flouting a maxim) is important for literary texts, because it is the only possible kind of non-fulfilment in a literary speech situation. As we are dealing with the Bible as literature, this aspect is of extreme importance for our purposes. Grice (1975:49) explains how the flouting or deliberate non-fulfilment of the CP and maxims can necessitate implicature: 
He may flout a maxim; that is, he may blatantly fail to fulfill it. On the assumption that the speaker is able to fulfill the maxim and do so without violating another maxim [because of a clash]....and is not, in view of the blatancy of his performance, trying to mislead, the hearer is faced with a minor problem: how can his saying what he did say be reconciled with the supposition that he is observing the overall $\mathrm{CP}$ ? This situation is one which characteristically gives rise to a conversational implicature.

Whenever flouting has taken place, it is necessary to decode the utterance in order to make sense of it. I am in agreement with Pratt (1977:163) that, in literature and literary speech situations, it is always the flouting of a maxim that is relevant whenever there is some sort of failure to fulfil a maxim. This means that whenever flouting has taken place in literature, it is always the intention that this situation is resolved by implicature. It must be stressed, however, that this fact is valid only for the communication between implied author and readers of the text. But it is, of course, also possible that the fictional speaker or character is failing to fulfil a maxim or the $\mathrm{CP}$ in the fictional (re)construction of a verbal exchange. This failure of a fictional character to observe the $\mathrm{CP}$ can even result in the breaking off or failure of the conversation on the level at which the characters are interacting. But the $\mathrm{CP}$ between implied author and readers is not violated, or rather the readers assume that it is not, and 'it is this assumption which determines the implicatures by which we resolve the fictional speaker's violations at the level of our dealings with the author' (Pratt 1977:175). The flouting of the above listed maxims results in a number of so-called figures of speech such as metaphor, hyperbole, meiosis and irony. In this respect speech act theory provides a novel way of looking at these phenomena and of explaining and identifying them.

It must be kept in mind, however, that the $\mathrm{CP}$ and maxims can be unintentionally non-fulfilled. In this case the participants in a conversation assume that the $\mathrm{CP}$ is still being observed, but they have to deduct and infer meaning from what is said. These implicatures are called conversational implicatures and represent the various calculations we make in order to make sense of what is said. For instance, if the following exchange is considered:
A: Are you coming along?
$\mathrm{B}$ : What time is it? 
It could be that $B$ is deliberately ignoring A's remark, or does not want to consider A's invitation. He/she could be deliberately avoiding A's statement and so trying to change the subject. Or B could be implicating that he/she is seriously considering A's invitation, provided that the hour is not too late. It is clear that more than one explanation of B's reaction is possible. This concept is frequently used by authors (and speakers of language) who are interested in exploiting multiple meanings, such as the Gospel of John. But the fact remains that the CP is considered as still being observed and thus, by implicature, it is possible to understand exactly what the writer or speaker is implicating.

Implicature where the CP is considered to be observed is also important in narrative texts as far as causal and chronological sequence can be established by this. Speakers seldom furnish full information or detail with regard to this, and the sequence must be determined by implicature. It would be useful for readers if a storyteller were to give full details as to which expression is part of the background information, which is evaluative, and which is part of the narrative sequence; but this would make an act of communication very cumbersome and unattractive. This is why most narrators rely on implicature to convey the relevance that can be ascribed to any particular unclear expression (see also McLaughlin 1984:32; Du Plessis 1988).

\subsection{Shared knowledge, beliefs and presumptions}

These aspects are of cardinal importance in speech act theory. In the communication process a hearer/reader of an utterance depends not only on the utterance itself to make sense of what the speaker/author is saying, but also on contextual knowledge which both parties share. This shared knowledge to a great extent determines the understanding and interpreting of an utterance. Bach \& Harnish (1979: 5-6) call this shared knowledge mutual contextual beliefs (MCBs). Facets which are important in this regard include knowledge of the specific speech situation, social knowledge, knowledge of traditional beliefs and presuppositions, cultural knowledge, knowledge about relationships between parties, and the implications of the relationships.

In addition to this there are a number of presumptions which both the author/ speaker and the reader/hearer must share in order to make communication possible. The linguistic presumption (Bach \& Harnish 1979:7) is the presumption that both parties are acquainted with the language and that both are able to handle the language adequately. The communicative presumption (Bach \& Harnish 1979:7) is the presumption that when the author of an utterance is saying something to another party, 'he is doing it with some recognisable illocutionary intent'. The 
presumption of literalness (Bach \& Harnish 1979:61; Du Plessis 1988:204) is the presumption that as long as a speaker's/author's utterance can be taken literally, it will be. If, however, a hearer/reader becomes aware that the intention is that he/ she should not take the utterance literally, the non-literal meaning of the utterance should then be established.

The above is, of course, of cardinal importance in establishing the exact meaning of non-literal speech acts. This knowledge forms the basis on which the inference as to the exact meaning and intention of an utterance is made.

\subsection{Indirect speech acts}

Many speech acts are indirect speech acts - that is, many speech acts do not have a literal illocutionary force. If the illocutionary force cannot be determined by either the performative verb or the form of the utterance, then we have an indirect speech act. For instance the sentence, 'Can you get me something for the stove?' has the literal illocutionary force of a question. It has, however, the indirect illocutionary force of requesting. However, the problem arises that often an utterance is unmarked by both form or explicit performative verb with regard to its illocutionary force, (see also Huddleston 1976:128-129; Stubbs 1983:158). The problem is how to determine the exact meaning of the utterance without an indication of what illocutionary force is at stake. This seems to be an as yet unresolved problem in speech act theory (see Van Jaarsveld 1987:8). Leech (1983:37-39) severely criticises this concept of indirect speech acts, and argues that his problem-solving strategy and the implicatures arrived at correspond to Searle's indirect speech acts. For him, all acts can be described as indirect speech acts, and this necessitates his distinction.

\subsection{Literary works and audiences}

In a natural speech situation there are a number of 'rules' governing the participation and non-participation of the parties involved. Rules such as turn-taking, length of utterance, and obligations to non-speaking participants are all important in a natural speech situation (Schleghoff 1973:12-14). However, in situations where something is narrated or when the right to participate in a speech situation is given up, such as by attending a public lecture, then an audience is created, and notably a voluntary audience. This audience is held captive by the speaker, because they cannot just interrupt, correct him/her, add to, change the subject or leave without seriously breaking certain fixed rules of behaviour. But the fact that the audience has given up certain privileges also implies that the speaker has a number of added obligations placed on him/her by the audience. He/she must ensure that his/her contribution is worthwhile, and a good one that keeps the audience's attention. The 
audience is therefore justified in expecting more of a speaker in this situation than in a situation where they can freely participate. This is also true of the literary speech situation. The readers of a text knowingly and willingly enter into a situation in which the speaker has unique access to the floor. Thus the audience-speaker relation also comes into play in literary texts with obligations to both sides and a commitment to one another. Readers feel and expect that the writer is under an obligation to make his text worthy of their attention and thus are willing to allow the writer some freedom and to bring their own behaviour into line with what can be expected of an audience. This is equally important for ancient texts, and the exact relationship between speaker and audience at a specific time and in a certain context, and the specific rules observed in that context for the speaker/audience situation, implied in the text, must be determined. The assumptions made by the readers (ancient and modern) at the beginning of the reading process are also important, as well as the care taken by some authors to reassure their audiences. The selection and preparation that went into the formation of the text are also important presuppositions we bring to bear when a literary work is read. This can indeed play an important part in the interpretation and reception of a text. (See Pratt 1977:116-125, 170 for an extensive discussion on this aspect.)

\subsection{Literary speech acts as 'display texts'}

Pratt (1977:132-151) argues strongly for the characterisation of literary texts as 'display texts', because of the principles of assertability and tellability (interesting and new information) which come into play when narratives (natural or otherwise) are represented. A speaker, when making an assertion whose relevance is not merely informing, but also tellable, is 'not only reporting but also verbally displaying a state of affairs, inviting his addressee[s] to join him in contemplating it, evaluating it, and responding to it. His point is to produce in his hearers not only belief but also imaginative and affective involvement in the state of affairs he is representing and an evaluative stance toward it. He intends them to share his wonder, amusement, terror or admiration of the event' (Pratt 1977:136).

According to this argument, some literary narrative texts can be classified as 'display texts' with the purpose of verbally representing situations, experiences and so on which are of an unusual or problematic nature. The story or narrative is then related with the aim of inducing the audience to react in the intended way and to adopt the intended viewpoint and subsequently to participate with vigour in the whole experience represented and (re)created in the literary work. This is of major importance for our analysis of biblical texts, since they too can be classified as display texts in Pratt's terms. 


\subsection{The literary speech situation}

It is the contention of this paper that literary works are also speech acts, and that most, if not all, principles that are relevant to speech act theory regarding natural narrative also come into play when a literary work is read.

In the literary speech situation, the communication between the speaker and the addressee can also in literary terms be described as a conversation that is taking place between author and reader. But it can only become a conversation if there is some sort of reaction on the side of the addressee. He/she must cooperate in order to constitute a valid literary conversation. It is therefore important also to keep the concept of Grice's (1975:45) cooperation principle and maxims in mind when dealing with a literary work. Whenever one of these CPs is transgressed, certain implications arise which must be resolved. If these are not resolved, the consequences are that even the literary speech situation could be in danger of breaking down that is, inducing the reader to stop reading and close the book. But the main implication from the above is that within speech act theory the literary communication process is seen as a conversation. The complex nature of the communicative situation in a literary text is related to the fact that there is communication and conversation on different levels. Within a literary work, and especially in a narrative, there are quite a number of levels on which the literary conversation takes place, and which have different participants, different speech acts, and different aims at each level.

Within a narrative literary work, the following participants are involved:

* Firstly, the real or concrete author and the concrete addressee. Both stand outside the text and the literary work and are thus not part of the literary enquiry.

* Secondly, there are the abstract author and reader, also called the ideal or implied author and reader. Both are evoked by the narrative.

* Thirdly, we find the narrator. This is the voice that tells the story. $\mathrm{He} / \mathrm{she}$ addresses himself/herself to a narratee or fictional reader. Whereas the abstract or implied author operates within the literary work, the narrator is part of the represented world - the total world of the literary work. The represented world is what the implied author presents the implied reader with. The narrator presents the narratee with the narrated world, which is inhabited by personations or characters, the fourth level.

* Fourthly, the personalities or characters also communicate with each other. They are present in the narrated world and have to do with the cited world, which consists of what a character says, believes and does. 
The above distinctions between and delineation of the participants in a narrative communicative situation are generally based on the model of Chatman (1978). Staley (1986:36-89) also uses this basic scheme and gives a full discussion of each of these facets in narrative. Schmid (1973:29), Carter (1988:57) and Watson (1988:50) offer schematic representations of the literary communicative situation. There has, of course, been some critique regarding terminology and concepts such as the implied author. Harley (1987:61-63) gives a good account of the differences in terminology regarding these terms as they are used by Schmid, Bal and others. Staley (1986:47-54) also deals with, inter alia, the objections raised by Bal (1981).

Because of the existence of these different levels, different participants may react differently to the same speech acts. The implied reader could, for instance, react independently and differently from the narratee or a character. This is because each participant is involved in a different speech act/conversation from the others. Furthermore, it must be stressed again that, just as a live conversation between two people is not conducted out of context, the context of the literary speech act must also be taken into consideration. Because of this fact certain felicitous conditions or appropriateness conditions valid for the historical situation and participants, and the conventions applicable for each level of communication, must be kept in mind.

We have already referred briefly to genre, but in this context the importance of genre and the knowledge of genre must be stressed. The nature of the text and the knowledge of the nature of the text imply that certain rules are at play. The act of reading implies that the reader to some extent places some expectation on his/her reading. $\mathrm{He} /$ she expects certain things from certain types of texts.

In sum, in order to account for the full range of implicatures for which the reader of a literary work is responsible, a description of literary speech acts will...have to take into account both the $\mathrm{CP}$ and maxims as defined for the work's genre and the $\mathrm{CP}$ and maxims as defined for the fictional speaker's utterance. While only the latter are required to decode what the fictional speaker is saying, both sets of appropriateness conditions are required to decode what the author is implicating. Readers of fictional literary works...automatically distribute their expectations in this way.

(Pratt 1977:203) 


\section{CONCLUSION}

The above are some of the more important aspects of speech act theory, which are cardinal to understanding the basics of the theory. Naturally, there are a number of different approaches within speech act theory (Hutchinson 1984:3-34; White 1988:124). What I have presented so far is what White (1988:4) calls the centrist position, as we have already indicated. I realise, of course, that the above is merely an introduction to speech act theory, but at the same time this should hopefully allow for attempts at the utilisation of speech act theory by those not schooled in all the intricacies of the theory.

For detailed discussions of speech act theory in general, the following are useful as reference works: Pratt (1977), Bach \& Harnish (1979), Lanser (1981), Leech (1983), McLaughlin (1984), Cloete (1984), Van Jaarsveld (1987), and White (1988). For discussions of aspects of speech act theory, see Lanigan (1977), Van Dijk (1972), Wierzbicka (1980), Van Jaarsveld (1982, 1987), Van Coller \& Van Jaarsveld (1984), Bax (1985), Felman (1983), and Van Eemeren \& Koning (1981).

In a following article I shall begin to show how the concepts so far described can enhance the exegesis of biblical texts, and in what way this theory provides new and fresh ways of approaching these texts.

\section{Works cited}

Amante, D J 1981. The theory of ironic speech acts. Poetics Today 2, 77-96.

Arens, E 1982. Kommunikative Handlungen: Die paradigmatische Bedeutung der Gleichnisse Jesu für eine Handlungstheorie. Düsseldorf: Patmos.

Aurelio, T 1977. Disclosures in den Gleichnissen Jesu: Eine Anwendung der disclosure - Theorie von I T Ramsey, der modernen Metaphorik und der Sprechakte auf die Gleichnisse Jesu. Frankfurt: Lang. (Regensburger Studien zur Theologie 8.)

Austin, J L [1962] 1975. How to do things with words. Oxford: Clarendon.

Bach, K \& Harnish L M 1979. Linguistic communication and speech acts. Cambridge: MIT.

Bal, M 1981. The laughing mice, or: On focalization. Poetics Today 2, 202-210.

Bax, M M H 1985. Oordelen in taal: Semantische en pragmatische aspecten van evaluaties in narratieve communicatie. Groningen: Wolters-Noordhof.

Botha, J E 1989. A study in Johannine style: History, theory and practice. DTh dissertation, University of South Africa.

Broich, U \& Pfister, M (Hrsg) 1985. Intertextualität: Formen, Funksionen, anglisistischen Fallstudien Tưbingen: Niemeyer. 
Carter, D 1988. The wild bunch and violence in film. Foundations and Facets Forum 4, 54-64.

Chatman, S 1978. Story and discourse: Narrative structure in fiction and film. Ithaca: Cornell University Press.

Cloete, T T 1984. Taalhandelinge en die literatuur, in Van Coller \& Van Jaarsveld 1984:1-14.

Cole, P \& Morgan, J L (eds) 1975. Syntax and semantics, vol 3: Speech acts. New York: Academic.

Combrink, H J B 1988. Readings, readers and authors: An Orientation. Neotestamentica 22, 189-203.

Culpepper, R A [1983] 1987. Anatomy of the Fourth Gospel: A study in literary design. Paperback. 2nd ed. Philadelphia: Fortress.

Derrida, J 1976. Of grammatology, tr by G C Spivak. Baltimore: John Hopkins.

..- 1979. Living on: Border lines, in Bloom, $\mathbf{H}$ et al (eds), Deconstruction and criticism, 75-176. London: Routledge and Kegan Paul.

Du Plessis, J G 1985. Clarity and obscurity: A study in textual communication of the relation between sender, parable and receiver in the Synoptic Gospels. DTh dissertation, University of Stellenbosch.

-- 1988. Why did Peter ask his question and how did Jesus answer him? or: Implicature in Luke 12:35-48. Neotestamentica 22, 311-324.

Edwards, R A 1985. Matthew's story of Jesus. Philadelphia: Fortress.

Eslinger, L 1987. The wooing of the woman at the well: Jesus, the reader, and reader-response criticism. Journal of Literature and Theology 1, 167-183.

Felman, $S$ 1983. The literary speech act: Don Juan with $J$ L Austin or seduction in two languages, tr by C Porter. Ithaca: Cornell University Press.

Fowler, R M 1981. Loaves and fishes: The function of the feeding stories in the Gospel of Mark. Chico: Scholars Press. (SBL dissertation series 54.)

--- 1982. Using literary criticism in the Gospels. The Christian Century 26, 626-629.

--- 1985. Who is 'the reader' in reader response criticism? Semeia 31, 5-23.

Grice, H P 1975. Logic and Conversation, in Cole \& Morgan 1975:41-58.

Gunderson, K 1975. Language, mind and knowledge. Minneapolis: University of Minneapolis Press.

Harley, L 1987. Wolf Schmid se kommunikasiemodel as basis vir die dualiteitsbegrip: Abstrakte outeur as wesens- en digterpersoonlikheid. Joumal of Literary Studies 3, 60-70.

Harty, E R 1985. Text, context, and intertext. Journal of Literary Studies 1/2, 1-13.

Heil, J P 1989. Reader-response and the irony of Jesus before the Sanhedrin in Luke 22:66-71. $C B Q$ 51, 271-284. 
Huddleston, R O 1976. An introduction to transformational syntax. London: Longman.

Hutchinson, C 1984. The act of narration: A critical survey of some speech act theories of narrative discourse. Joumal of Literary Semantics 13, 3-34.

Iser, W 1978. The act of reading: $A$ theory of aesthetic response. Baltimore: John Hopkins.

-- 1980. Interaction between text and reader, in Suleiman \& Crosman 1980: 106119.

Jacobs, L D 1985. Taalhandelinge en strategieë in 1 Korinthiërs 1-4. MA thesis, University of the Orange Free State.

Jefferson, A \& Robey, D (eds) 1987. Modern literary theory: A comparative introduction. 2nd ed. London: Batsford.

Lanigan, R L 1977. Speech act phenomenology. The Hague: Nijhoff.

Lanser, S S 1981. The narrative act: Point of view in prose fiction. Princeton: Princeton University Press.

Leech, G N 1983. Principles of pragmatics. London: Longman.

McLaughlin, M L 1984. Conversation: How talk is organized. Beverly Hills: Sage.

Maclean, I 1987. Reading and interpretation, in Jefferson \& Robey 1987:122-144.

Ohman, R 1973. Literature as act, in Chatman, S (ed), Approaches to poetics: Selected papers for the Institute, 81-108. New York: Columbia University Press.

Patte, D 1988. Speech act theory and biblical exegesis. Semeia 41, 85-102.

Petersen, N R 1984. The reader in the Gospel. Neotestamentica 18, 38-51.

Platt, J T \& Platt, H K 1975. The social significance of speech: An introduction to and workbook in sociolinguistics. Amsterdam: North Holland. (North Holland Linguistic Series 23.)

Pratt, M L 1977. Towards a speech act theory of literary discourse. Bloomington: Indiana University Press.

Ryan, R 1985. Pathologies of epistemology in literary studies. Journal of Literary Studies 1/1, 3-42.

Ryan, R \& Van Zyl, S (eds) 1982. An introduction to contemporary literary theory. Johannesburg: Donker.

Schleghoff, E A 1973. Recycled turn beginnings: A precise rapid mechanism in conversation turn taking organization. Public lecture in the series 'Language in the context of space, time and society', Summer Institute of Lingistics, University of Michigan July 1973. Mimeographed.

Schmid, W 1973. Der Textaufbau in der Erzählungen Dostoevskijs. München: Fink.

Searle, J R 1975. A taxonomy of illocutionary acts, in Gunderson 1975:344-369.

-- 1976. A classification of illocutionary acts. Language in Society 5, 1-23. 
Searle, J R [1969] 1977. Speech Acts: An essay in the philosophy of language. Cambridge: Cambridge University Press.

Staley, J L 1986. The print's first kiss: $A$ hetorical investigation of the implied reader in the Fourth Gospel Ann Arbor: University Microfilms International.

Stubbs, M 1983. Discourse analysis. Oxford: Blackwell.

Suleiman, S R \& Crosman, I (eds) 1980. The Reader in the text: Essays on audience and interpretation. Princeton: Princeton University Press.

Van Coller, H P \& Van Jaarsveld, G J (reds) 1984. Woorde as dade: Taalhandelinge en letterkunde. Durban: Butterworth.

Van Coller, H P \& Van Rensburg, M C J 1984. Suggesties, implikasies en afleidings, in Van Coller \& Van Jaarsveld 1984:86-98.

Van Dijk, T A 1972. Some aspects of text grammars. The Hague: Mouton.

Van Eemeren, F H \& Koning, W K B (reds) 1981. Studies over taalhandelingen. Amsterdam: Boom.

Van Jaarsveld, G J (red) 1982. Wat sê jy? Studies oor taalhandelinge in Afrikaans. Johannesburg: McGraw-Hill.

-- 1987. Wat bedoel jy? Pretoria: Serva.

Vorster, W S 1984. The historical paradigm: Its possibilities and limitations. Neotestamentica 18, 104-123.

--- 1986. The New Testament and narratology. Joumal of Literary Studies 2, 52-61.

--- 1987. Op weg na 'n post-kritiese Nuwe-Testamentiese wetenskap. HTS 43, 374394.

--- 1988. The Protevangelium of James and intertextuality, in Baarda, T et al (eds), Text and testimony: Essays in honour of A F J Klijn, 262-275. Kampen: Kok.

... 1989. The in/compatibility of methods and strategies in reading or interpreting the Old Testament. Old Testament Essays 2, 53-63.

Watson, N 1988. Reception theory and Biblical exegesis. Australian Biblical Review 36, 45-56.

Wendland, E R 1985. Language, society and Bible translation: With special reference to the style and structure of segments of direct speech in the Scriptures. Cape Town: Bible Society of South Africa.

White, H C 1988. Speech act theory and literary criticism. Semeia 41, 1-24.

Wierzbicka, A 1980. Lingua Mentalis: The semantics of natural language. Sidney: Academic. 